\title{
The 2010 Regional Elections in Greece: Voting for Regional Governance or Protesting the IMF?
}

\author{
Kostas Gemenis \\ Department of Public Administration, University of Twente, Enschede, Netherlands \\ Preprint of the article published in Regional \& Federal Studies (2012) \\ 22(1): 107-115, DOI: 10.1080/13597566.2011.652095
}

\section{Introduction: Regional Governance in Greece}

On 7 and 14 November 2010, Greece held its first elections for the regional level of representation. The regional elections, which were held concurrently with municipal elections across the country, were the result of the latest local government reforms. In 1986, the governing Panhellenic Socialist Movement (PASOK) created 13 administrative regions on top of the 54 prefectures. These administrative regions ('peripheries' in Greek) did not always overlap with the historical regions of the country since they were devised as development regions in order to implement the EUfunded Integrated Mediterranean Programmes (Hooghe and Marks, 2001: 196) and to attract funds from the Community Support Frameworks which followed suit. The regional secretary generals (similar to the prefects but unlike the mayors and the municipal councils) were appointed by the central government. In 1994, PASOK 'municipalized' and transformed the prefectures into a second-tier of local government by initiating the direct election of prefects and prefecture councils which received a limited number of competencies (Hlepas, 2010: 228). In yet another reform implemented by PASOK in the late 1990s, the municipalities received extra funding and competences after a compulsory amalgamation into 924 municipalities and 100 rural communes (see Hlepas, 2010: 230-235). With the return of PASOK to power in 2009 (see Dinas, 2010; Gemenis, 2010; Pappas, 2010) another compulsory amalgamation was initiated, this time reducing the number of municipalities to 325 . Moreover, the prefectures were abolished and replaced by a regional tier of representation along the lines of the thirteen administrative regions.

Each region acquired a directly elected governor (periferiarchis) and regional council roughly proportional to its population. The Constitution stipulates that political parties are not permitted to contest local and regional elections 
and, therefore, the elections are contested by open regional lists headed by a candidate governor. In practice, however, most of these lists are openly created, supported or otherwise endorsed by political parties. It is often the case that political parties will use their local organizations in order to put together a list, whereas MPs will head the lists as candidate governors. Moreover, internal party disagreements can result in party cadres creating their own 'rebel' lists to compete against the party-endorsed list. Particular local circumstances may also induce several parties to support a single list or facilitate the creation of genuinely independent lists.

The elections for the regional governors and councils take place every five years under a two-round majority run-off electoral system where the winning list elects the governor. The council seats, however, are allocated under a complex electoral formula. When the winning list receives more than $60 \%$ of the vote in the first round, all seats are allocated proportionally. When the winning list earns between $50 \%$ and $60 \%$ of the vote in the first round, it earns three-fifths of the seats, whereas the remaining two-fifths are allocated proportionally among the remaining lists. In the case where no list earns at least $50 \%$ in the first round, half of the seats are allocated proportionally among all the lists, and the first two lists contest the second round. The remaining half of the seats are allocated after the second round, with the winner earning as many seats needed in order have the three-fifths of the total and the loser earning the remaining seats. This formula is capable of particularly disproportional allocations of seats, especially in regions where more than $75 \%$ of the vote in the first round is shared roughly equally among three or four lists. Regardless of the disproportional formula, however, the absence of a legal threshold and the relatively large district magnitude creates incentives for small parties and independents to contest on lists of their own.

\section{Background}

The 2010 regional elections took place roughly a year after the 2009 parliamentary election. At the outset, PASOK began its term with an ambitious programme centred on the promise of a $€ 3$ billion stimulus package for the economy and 'green development' which was reflected in a remarkably high level of support in the opinion polls (Gemenis, 2010: 360). Soon enough, however, the government found itself in the middle of a serious fiscal crisis and, after rallying for the creation of a support mechanism by the EU and the International Monetary Fund (IMF), asked for a bailout on 23 April (Gemenis, 2010: 361). As the Greek government negotiated the terms of the bailout (dubbed 'the memorandum') with the representatives of the European Commission, the European Central Bank and the IMF (dubbed 'the troika'), its popularity rapidly decreased in the opinion polls (Figure 1). As it became clear that the economic and fiscal policies outlined in the memorandum included harsh austerity measures, trade 
unions and parties of the opposition staged a series of large-scale protests. The protests turned violent when the government brought the memorandum to be ratified in the parliament. During a demonstration, three bank employees were killed after masked protesters threw petrol bombs into the building where they were working.

The ratification statute voted by the parliament on a majority of 172 (out of 300) showcased a rather peculiar set of accords. The Communist Party of Greece (KKE) and the Coalition of the Radical Left (SYRIZA) both voted against. Although the radical-right Popular Orthodox Rally (LAOS) voted in favour, the conservative New Democracy (ND) decided to tactically vote against the statute. ND MP and former minister Dora Bakoyannis, however, voted in favour and cited her (neo-)liberal credentials for doing so. It was clear, nevertheless, that Bakoyannis was disgruntled after losing the previous yearâÁŹs party leadership election to Antonis Samaras (Gemenis, 2010: 359-360) and when Samaras expelled her from ND, she announced the possibility of forming her own party. Bakoyannis was not the only MP who went against the party whip. Three PASOK MPs abstained and the PASOK leader George Papandreou quickly expelled them from the parliamentary caucus.

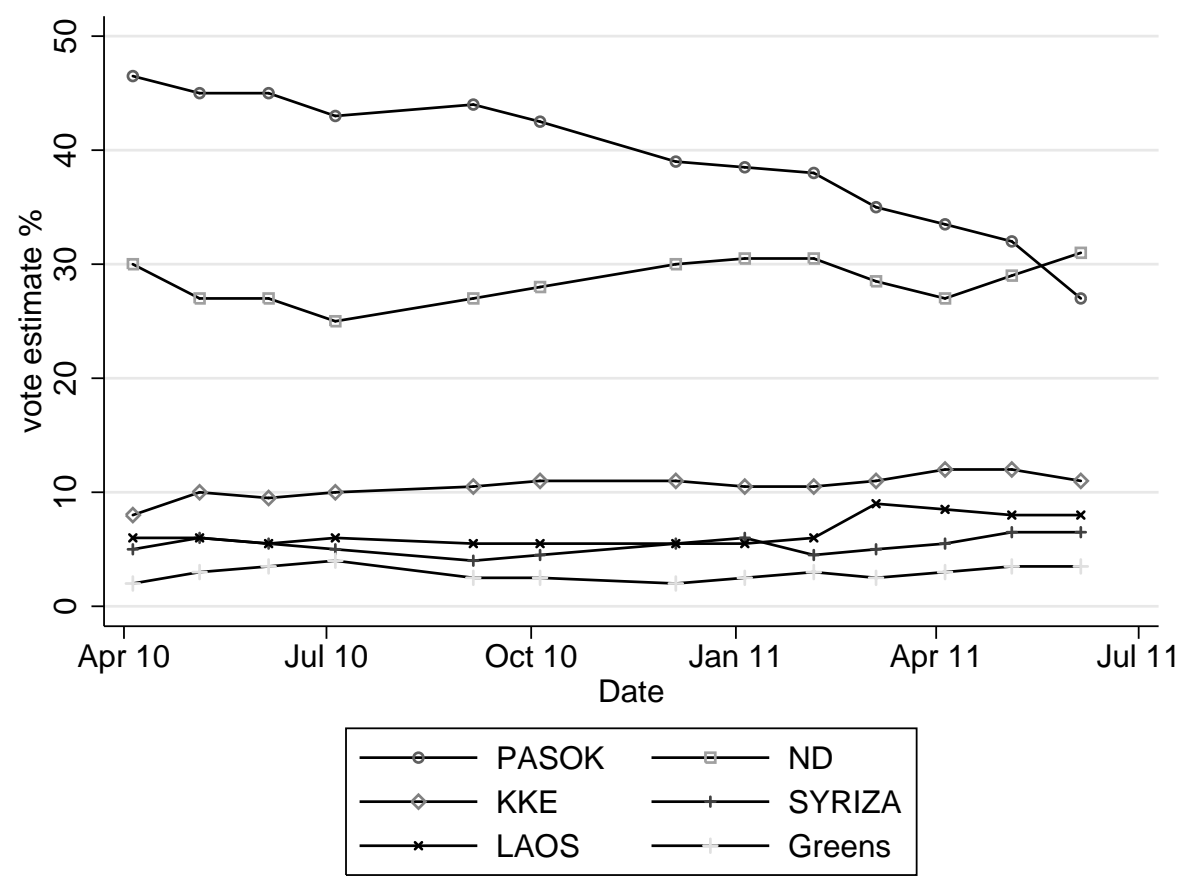

Figure 1: Opinion polls voting estimates, April 2010-June 2011. Source: Data from the Public Issue Barometer (various editions), available at http://www.publicissue.gr

As strikes and protests became a daily occurrence, the government tried 
in vain to convince citizens that the measures were necessary. The opposition, however, was unable to propose a viable or credible alternative to the memorandum. Samaras suggested that his party would ensure a bailout without the need of adopting a memorandum but failed to point out who would be willing to lend money to Greece without any guarantees that the country would be able to pay back its lenders. The KKE suggested that Greece should restructure its debt and pull out from the EU whereas the aged music composer Mikis Theodorakis advanced conspiracy theories and internet rumours that China had agreed to pay off Greece's debt. SYRIZA was also hindered in its attempt to mount a successful opposition against the government and the troika due to its acute infighting (see Gemenis, 2010: 355-356). In February 2010, the former SYRIZA leader, Alekos Alavanos, announced the creation of a separate umbrella group within the SYRIZA coalition and left open the possibility of transforming it into a new party. Moreover, at the 6th party congress of Synaspismos (SYN), the largest constituent of the SYRIZA coalition, in the following June many members of the Europeanist Ananeotiki faction walked out and announced their intention to create a new political party. The new party was soon named Democratic Left and included four defected SYN MPs (reducing the SYRIZA parliamentary group to nine MPs) as well as several hundred SYN members. Under these circumstances, the opposition failed to capitalize on the widespread discontent and the government was able to proceed with the announced measures due to its clear parliamentary majority.

Against this background, PASOK decided to put together lists for 12 out of the 13 regions, the exception being Peloponnese where the party decided to support the list of independent Petros Tatoulis, a long-time ND MP who resigned his party whip in November 2008. PASOK, however, had to face some rebels of its own. Yiannis Dimaras, one of the three MPs ousted by Papandreou, and Giorgos Kaloudis announced that they would contest Attica and Ionian Islands, respectively, with independent 'anti-memorandum' lists. Unlike PASOK, ND decided to put together lists in all 13 regions, but apart from the aforementioned rebel in the Peloponnese, they had to confront another rebel list in Crete which was tacitly supported by Bakoyannis. As in previous prefecture elections, LAOS adopted a pick-and-mix strategy by putting together lists in six regions, supporting ND candidates in another four, supporting one independent with PASOK (Peloponnese) and completely avoiding the socialist bulwarks of Crete and East Macedonia \& Thrace.

On the left, SYRIZA and the Democratic Left managed to compile eleven and six lists, respectively, whereas the Ecologist Greens put together eight, as well as three with the Democratic Left and another two with SYRIZA. Moreover, SYRIZA saw Alavanos rebel against the coalition candidate in Attica. Alavanos contested Attica supported by his umbrella group which included some of SYRIZA's constituent parties. Unsurprisingly, KKE was the only party that managed to compile lists in each and every region (consistently named 'Popular Mobilization in [region]') by avoiding both the emergence of rebels and the 
formation of electoral coalitions. Finally, a coalition of extreme left parties, the Front of the Greek Anticapitalist Left (ANTARSYA, a pun on 'mutiny' in Greek) compiled lists in eleven regions whereas far-right groups did so in another two.

\section{The Election Campaign}

Undoubtedly, a big portion of the campaign focused on the candidate governors who were heading the lists. PASOK adopted the strategy of fielding highly politically experienced persons as candidate governors. Ten out of their twelve candidates were currently serving as prefects or MPs (including three junior ministers). LAOS followed this strategy as well, with four active MPs, whereas half of KKE and the Democratic Left candidates were either active or former MPs. Conversely, SYRIZA and the Ecologist Greens showed a preference for candidates who had previously served as prefecture councillors. Although ND was particularly interested in capturing as many regions as possible, the fact that Samaras was still seeking to consolidate his leadership meant that ND would not nominate many MPs and prefects who did not support Samaras in his bid for leadership. This can, therefore, explain choices like Vassilis Kikilias, a former basketball player with little political experience, as the candidate for the region of Attica which includes the wider Athens metropolitan area. Finally, another interesting fact was that, although the law required lists to consist of at least onethird of female candidates, only four of the 92 candidate governors were women (all supported by parties of the left).

As soon as active campaigning began, it became clear that the candidates faced a choice between emphasizing issues relating to regional governance or try to turn the election into a protest against the memorandum and the troika. PASOK insisted that the elections should focus on regional government issues and that the election result should not necessarily reflect the popularity of the government. The Ecologist Greens and the Democratic Left also supported this view and hoped that they could attract votes on the virtue of their local government programmes and quality of candidates. For ND candidates and the PASOK rebels, such as Dimaras, playing the anti-memorandum card offered a good opportunity to take advantage of popular resentment over the austerity measures and increase their share of the vote. Nevertheless, since the governors would not be able to influence government policy, voting for an antimemorandum candidate could be interpreted only as a symbolic gesture. As a consequence, both Dimaras and the candidates supported by ND reached a compromise by publishing detailed manifestos which focused on local government issues but nevertheless reiterated their opposition to the memorandum and the troika. This prompted KKE to condemn them as opportunists. Similarly to other candidates of the left, the candidates of KKE campaigned almost exclusively on an anti-memorandum platform, something hardly surprising considering that KKE opposed the latest local government reforms in the first instance. 
Finally, LAOS, having voted in favour of the memorandum, had no choice but to focus on other issues, such as law and order, and immigration.

As Papandreou realized that adherence to the regional character of the elections would not be the most effective strategy against candidates who combined a detailed regional election programme with anti-memorandum rhetoric, he decided to change course of action. In a highly publicized interview which was broadcast on 25 October, Papandreou confirmed that the government viewed the elections as a vote of confidence on government policy as much as a contest about electing regional governors and councils. Papandreou announced that, in the event where PASOK would lose the regional elections, he would call for a snap parliamentary election sometime in the first half of 2011. Papandreou hoped to mobilize PASOK voters and steer those who intended to vote for the anti-memorandum candidates, such as Dimaras, into abstaining. This decision was met with criticism by the Ecologist Greens and the Democratic Left which were left alone in supporting the regional character of the elections, whereas the other opposition parties condemned it as blatant political blackmail.

\section{Interpreting the Results}

In the first round of 7 November PASOK managed to elect two of its candidate governors (Crete and South Aegean) whereas another five of its supported candidates headed the election into the second round. Most importantly, Dimaras came third in the largest region of Attica and the second round against Kikilias of ND was seen by PASOK as an easy victory (Table 1). The second round of 14 November, confirmed these expectations and PASOK ended up controlling a total of seven regions and $43.6 \%$ of the council seats. Seen in conjunction with the second round victories in the Athens and Thessaloniki municipal elections which were held on the same day ${ }^{1}$ and against the decline at the opinion polls, PASOK considered the result as a moderate victory. Nevertheless, if we were to translate support for PASOK candidates to support for PASOK, then we would notice that the elections showed a sharp decline in the PASOK vote. In fact, PASOK won the lowest absolute number of votes since 1977. More than anything, however, PASOK avoided a crushing defeat and Papandreou announced that the government would not consider an early election in 2011.

ND managed to elect five governors including two with the support of LAOS. Although it was clear that ND did not win the elections, Samaras claimed that the results signalled a 'total recall' for his party and that the difference to PASOK was diminished. In the regions where PASOK and ND supported candidates independently of LAOS, ND was approximately $2 \%$ behind PASOK. However, if we take into account that ND supported more candidates with LAOS than PASOK did, the difference between PASOK and ND was probably higher, probably around $4.3 \% .^{2}$ The enthusiasm of Samaras can, therefore, be justified 
only from the perspective of the 2009 defeat where ND had the worst electoral result in its 35-year history. Moreover, Samaras' personal choice of supporting candidates, such as Kikilias, may have cost ND a victory, but consolidated his leadership.

Although LAOS leader Georgios Karatzaferis spoke of a success for his party, the results show that his party fared very badly in the elections. LAOS candidates fared consistently worse than the 2009 parliamentary election. For instance, in Attica, LAOS MP Adonis Georgiadis got only $6.57 \%$ of the vote (calculated by aggregating the four constituencies of the region) compared to the $7.2 \%$ of 2009. Similarly, in the constituency of Kastoria where LAOS came third in $2009(4.46 \%)$ its share in 2010 was only $2.7 \%$. Most likely the results were related to the controversial decision of LAOS to support the memorandum in parliament. It seems, therefore, that Karatzaferis enthusiasm had more to do with LAOS emerging as a credible coalition partner of ND under the new leader (cf. Gemenis, 2008: 97; 2010: 356-357) than anything else.

Conversely, KKE could claim a small victory as it increased both its share of the vote and the absolute number of its voters. SYRIZA, however, fared worse than expected which is probably not surprising considering the fierce competition it faced since the left of the political spectrum was overcrowded by parties trying to take advantage of the rather low effective threshold for representation. Having said that, the combined support for parties of the left was the greatest since the parliamentary election of 1981.

An important aspect of the regional elections was the low turnout (officially $60.88 \%$ and $46.68 \%$ for the two rounds, respectively) although there was considerable variation from region to region (Kafe et al. 2011). Considering, however, the poor record keeping in the Greek electoral register which inflates the number of registered voters (Gemenis, 2008: 98), true turnout for the first round has been estimated at $72.8 \%$ (Mavris, 2010). Spoiled ballots were around 5\%, higher than the 2009 parliamentary election but very similar to the 2006 municipal and prefecture elections. What is most important, however, is that the decrease in turnout did not affect all the candidates equally. It has been estimated that twice as many PASOK than ND voters abstained from the regional elections (Mavris, 2010). This implies that many PASOK voters who did not support the PASOK lists, avoided voting for any of PASOK's opponents simply by choosing to abstain. ND, therefore, failed to sow the seeds of discontent and the beneficiaries were primarily KKE and the small parties of the left.

\section{The Post-election Political Landscape: Towards Frag- mentation?}

The U-turn of PASOK after Papandreou's televised interview indicated that the first regional elections were destined to be fought as second-order national elections, where voters are expected to punish incumbent candidates and vote 
for the smaller parties (Mavris, 2003). In places, however, the vote had a local character associated with the personal background of the candidates rather than regional governance or national issues. Nevertheless, the disproportional electoral system, together with the low turnout and the fragmentation of the opposition allowed PASOK to win the election at least in terms of appearances and continue with the troika-proposed reforms. Popular discontent, however, remained strong and the strikes continued unabated.

At the parliamentary level this discontent was expressed with further fragmentation of the party system. Apart from the aforementioned split in SYN which established the Democratic Left as the sixth parliamentary party, Bakoyannis announced the creation of her own party the week after the second round of the regional elections. Called the Democratic Alliance, the party showcased the latest attempt to create a liberal-conservative party. By the end of January 2011, four MPs and one MEP resigned the ND whip and joined Bakoyannis, making Democratic Alliance the seventh party represented in parliament. Moreover, Dimaras, who previously announced that he would resign as anMP after his failure to be elected governor of Attica, changed his mind and decided to form a new party together with another ex-PASOK MP, whereas by June 2010 three additional MPs resigned the PASOK whip reducing the party's parliamentary caucus to 154 MPs.

The national issues surrounding the troika and the memorandum are clearly responsible not only for the observed fragmentation in the party system but also for the reluctance of parties and their candidates to set an agenda for regional governance. The 2010 regional elections can, therefore, be interpreted as a lost opportunity for regional governance and as a second-order election which signalled hard times ahead for the government and the country.

\section{Notes}

${ }^{1}$ The municipalities of Athens and Thessaloniki have been controlled by ND candidates since the mid-1980s. PASOK managed this double breakthrough by supporting independent candidates (former ombudsman George Kaminis in Athens and winemaker and environmentalist Yannis Boutaris in Thessaloniki) together with the Ecologist Greens and the Democratic Left.

${ }^{2}$ See Mavris and Symeonidis (2010). In the cases where ND and PASOK supported candidates together with LAOS, Mavris and Symeonidis subtracted the 2009 parliamentary election result of LAOS. The votes to ND and PASOK rebels were considered as votes for the respective parties, with the exception of the votes to Dimaras which were split among different parties according to the opinion poll estimates of Public Issue.

\section{References}

Dinas, E. (2010), The Greek General Election of 2009: PASOK—The Third Generation, West European Politics, Vol.33, pp.389-398.

Gallagher, M. (1991), Proportionality, Disproportionality and Electoral Systems, 
Electoral Studies, Vol.10, pp.33-51.

Gemenis, K. (2008), The 2007 Parliamentary Election in Greece, Mediterranean Politics, Vol.13, pp.95-101.

Gemenis, K. (2010), Winning Votes and Weathering Storms: The 2009 European and Parliamentary Elections in Greece, Representation, Vol.46, pp.353362.

Hlepas, N.-K. (2010), Incomplete Greek Territorial Consolidation: From the First (1998) to the Second (2008-09) Wave of Reforms, Local Government Studies, Vol.36, pp.223-249.

Hooghe, L. and Marks, G. (2001), Multilevel Governance and European Integration. Lanham, MA: Rowman and Littlefield.

Kafe, A., Nezi, R. and Pieridis, C. (2011) Poioi den psefizoun kai giati: melete tes apoches stis demotikes kai perifereiakes ekloges tou Noemvriou 2010 [Who abstains and why: an analysis of the November 2010 local and regional elections], Science and Society, No.27, pp.25-54.

Mavris, Y. (2003), Nomarchiakes ekloges 1994-2002: ekloges deuteres taxeos? [Prefecture Elections 1994-2002: Second-order Elections?], Greek Political Science Review, No.21, pp.95-105.

Mavris, Y. (2010), Ta 3+1 menymata tes 7es Noemvriou [The 3+1 messages of November 7], Kathimerini, 14 November.

Mavris, Y. and Symeonidis, G. (2010), Analysis, Public Issue, 21 December. Available at http://www.publicissue.gr/1616/monades-2010/ (accessed 21 February 2011).

Pappas, T. S. (2010), Winning by Default: The Greek Election of 2009, South European Society \& Politics, Vol.15, pp.273-287. 